\title{
Assessment of Ph.D Supervisors Role Performance in Educational Management Research for Sucessful Completion Rates in Universities of North Eastern Nigeria
}

\author{
Kabiru Mohammed Badau ${ }^{1}$ \\ ${ }^{1}$ Department of Physical Sciences Education, Modibbo Adama University of Technology, Yola, Nigeria \\ Correspondence: Kabiru Mohammed Badau (Ph.D), Department of Physical Sciences Education, Modibbo Adama \\ University of Technology, Yola, Nigeria. Tel: 234-3-806-8439.
}

Received: February 6, 2020

Accepted: March 8, 2020

Online Published: June 29, 2020

doi:10.5430/irhe.v5n2p33

URL: https://doi.org/10.5430/irhe.v5n2p33

\begin{abstract}
Changes in the funding and delivery of Ph.D educational management programmes at the university level, in recent years has resulted to significant changes in the role performance of Ph.D supervisors for successful completion rates. This paper assessed the role performance of supervisors of Ph.D in education management research. The purpose of the study was to specifically determine the role performance of Ph.D supervisors in formulation of the study, establishing the methods of study, discussing the results, presentation of seminars and conferences, publication of journal articles and writing of the dissertation in universities of North Eastern Nigeria. Six research questions guided the study. A sample size of 180 comprising of $80 \mathrm{Ph} . \mathrm{D}$ supervisors and $100 \mathrm{Ph} . \mathrm{D}$ students was utilized for the study. Data was collected using a researcher developed instrument from the six variables of $\mathrm{Ph} . \mathrm{D}$ supervisor's role performance. The findings of the study show that Ph.D supervisors role performance in formulating the study, establishing the methods of study, discussing the results, presentation of seminars and conferences, publication of journal articles, writing of dissertation and general role performance was high. The study concluded that $\mathrm{Ph} . \mathrm{D}$ supervisors performed their general role performance in all the stages of supervision for timely and successful completion rates in education management research. The study recommended assessment of the student's role performance for successful and timely Ph.D educational management research completion rates in North Eastern Nigeria.
\end{abstract}

Keywords: assessment, Ph.D supervisors, role performance, educational management research, completion rates, universities, North Eastern Nigeria

\section{Introduction}

The success of completion rates of Ph.D in educational management research is greatly influenced by the role Performance of supervisors. Supervisors have key role in ensuring timely supervision and completion of Ph.D research degrees in educational management (Teaching and Learning, 2015). This is determined through the knowledge, experience and competence of the supervisors in the process of supervision (Louw \&Muller, 2014). The level of difficulty associated with evidencing supervisory excellence is partly attributed to a variety of supervisory roles that exist and contribute to a candidate's research degree completion (Nulty, Kiley \& Meyers, 2008). Changes in the funding and delivery in Ph.D educational management programmes at the university level, in recent years has resulted to significant changes in the role performance of supervisors for successful completion rates(Howard\&Powell, 2005). Universities can improve their completion rates by using metrics to assess the role performance of supervisors(Reisz, 2017).

The role of a $\mathrm{Ph} . \mathrm{D}$ supervisor is to provide a high quality research and learning environment for the graduate students. The supervisor through mentoring, and advising, develops a professional interpersonal relationship with a graduate student that is conducive to scholarly activities, intellectual enhancement and promotes the student professional career (Chiappetta-Swamson\&Watt, 2011).

Ndakala (2008) specified the general roles of the supervisor for students guidance at every stage. From formulation of the study, establishing the methods of study to discussing the results of the study, presentation in seminars and conferences, presentation of journal articles and writing of the dissertation. 
Little research has been conducted into the roles supervisors must play towards their supervisee based on the experience of current doctoral students (Begin\&Gerard, 2013). According to Person and Brew (2002) and ManaThununga (2005), the supervisor's role should be addressed from a perspective that encompasses the specific demand of doctoral study. In their opinion, the purpose of a doctoral degree is to train competent researchers who will fit adequately into a working environment. In a content of confrontation between institutional pressures and labour market requirements, Ph.D supervisors should be helping students to navigate a viable pathway suited to their individual learning, needs and career goals (Aryanitakis, 2002).

Manathunga (2007) described supervisor behavior consistent with the understanding that supervisor guide and facilitate their student's development into independent researchers through empathetic dialogue and by modelling appropriate disciplinary based research behavior. Person and Brew (2002) continues that Ph.D supervisors socialized students into disciplinary research cultures to provide emotional support and assist with broader career development. Nayar\&Mccallun (2012) specified broad range of characteristics of good supervisor as enthusiasm, passion, sensations, respect, unselfishness, appreciating individual differences, balancing directions and self-directions, clearly with behaviors and characteristics of this kinds. It is a challenge capture evidence of role performance (Cartons, QFarrel \& Kelly, 2008).

Lee (2013) reviewed five factors as roles of Ph.D supervisors for successful dissertation. This includes management, administrative support, specific technical support, broadening intellectual support and personal support. The roles of a supervisor are professional roles. The supervisors concurrently may act in many roles as a coach, leader, friend, colleague, trainer, good role model and guide (Nulty, Kiley\& Meyers, 2008). Ph.D supervisors should be available to help their graduate students at any stage from foundation of the research project through establishing methodologies and discussing results to presentation and possible presentation of dissertations. Graduates supervisors must also ensure that student's works meet the standard of the university and academic discipline (Ndayambaje, 2015).

Nulty, Keyly\& Meyers (2008) provided model for thinking about reflecting on and delivery of richer and more structured supervisory experience to students. The model includes four roles: mentoring, sponsoring, progressing the candidate and coaching. Three dimensions characterize the contribution of a supervisor. The first, the nature of students group supervised. The second is the role of the supervisor. The third is whether the supervisor works alone with another or a team as principal or associate leader or team members (Carton, 2014). In general, the Ph.D supervisor has the primary academic responsibility for the organization and implementation of the study programme and most ensure documentation for complete participation in the professional course or equivalent qualifications (Sinclair, 2004).

Kuluyu (2016) reported that the role and functions of a research supervisor are multiple and vary in the perception of its different stakeholders. In the view of students, the ideal supervision helps them to achieve a scientific professional or personal goal and to learn about research and how to conduct research against the quality standards of their system. In the view of supervisors, their supervision should be able to contribute to the advancement of scientific knowledge through creating effective learning and research situations and entails opportunities for supervisors to conduct research projects with students which may contribute to ensure growth.

Everyone knows that some academics should never have been allowed to supervise $\mathrm{Ph}$.Ds in educational management research in universities. Institutions that tolerate this are falling in their duty of students care (Reisz, 2017). All Ph.D supervisors must be assessed on the number of past students, current load and an index design to capture outcome versus opportunities. Universities should reward Ph.D supervisors in educational management research for successful and timely completion and student's rescued from abandoning the dissertation but was persuaded to stay on. Universities wanted to pernalise non-completion and withdrawals owing to dissertation with supervisors but remained neutral about early withdrawals, student-initiated withdrawals for non-academic reasons and failed rescuing attempts. The result was a much more effective system for classifying and tracking the role performance of supervisors in educational management research. This can lead to the removal of the totally unsatisfactory supervisors and increase in timely completion. The result can also be utilized to support application for promotions and efforts made to reduce unnecessary wastage when arguing for additional scholarship support. Behaviors such as dragging failing students out until their scholarship run out is no longer seen as appropriate (Russell, 2017).

Universities goal is to create doctoral graduates who are creative, critical, autonomous intellectual risk takers and can act as drivers of their professional development. With skills development which is the cornerstone of modern doctorate, institutions should think of the candidate as the central product and the dissertation as just an important piece of supporting evidence (Bogle, 2017). Formal training is required for scholarships to optimize candidatures to 
hold the levels of funding and scholarships (Chiappetta-Swanson\&Watt, 2011). With few doctoral holders who end up working in academia, awareness should be raised among doctoral candidates on the importance of recognizing and enhancing the skills that they develop and acquire through research (Uribe, 2017).

\subsection{Purpose of the Study}

The purpose of the study was to assess the role performance of Ph.D supervisors in educational management research completion rates in universities of North Eastern Nigeria. Beyond the main purpose of the study, the specific objectives were to determine the role performance of Ph.D Supervisors of educational management research in:

1. Formulation of the study on Ph.D educational management research student's completion rates in universities of North Eastern Nigeria.

2. Establishing the methods of the study on Ph.D educational management research student's completion rates in universities of North Eastern Nigeria.

3. Discussing the results of the study on Ph.D educational management research student's completion rates in universities of North Eastern Nigeria.

4. Presentation of seminars and conference on Ph.D educational management research student's completion rates in universities of North Eastern Nigeria.

5. Publication of Journal articles on Ph.D educational management research student's completion rates in universities of North Eastern Nigeria.

6. Writing the dissertation on Ph.D educational Management research student's completion rates in universities of North Eastern Nigeria.

7. The general role performance on Ph.D educational management research students completion rates in universities of North Eastern Nigeria.

\subsection{Research Questions}

The following research questions guided the study.

1. What is the level of formulation of the study role performance of Ph.D supervisors on educational management research student's completion rates in universities of North Eastern Nigeria?

2. What is the level of establishing the methods of the study role performance of Ph.D supervisors on educational management research student's completion rates in universities of North Eastern Nigeria?

3. What is the level of discussing the results role performance of Ph.D supervisors on educational management research student's completion rates in universities of North Eastern Nigeria?

4. What is the level of presentation of seminars and conferences role performance of Ph.D supervisors on educational management research student's completion rates in universities of North Eastern Nigeria?

5. What is the level of publication of journal articles role performance of Ph.D supervisors on educational management research student's completion rates in universities of North Eastern Nigeria?

6. What is the level of writing the dissertation role performance of Ph.D supervisors on educational management research student's completion rates in universities of North Eastern Nigeria?

7. What is the level of general role performance of Ph.D supervisors on educational management research student's completion rates in universities of North Eastern Nigeria.

\section{Conceptual Model and Literature Review}

Louw \& Muller (2014) developed a logical model borrowed from programme evaluation to improve Ph.D supervisors role performance. The logical view comprises of the following three stages in the process:

1. Students access, selection and admission.

2. Financial and administrative support, supervisors department and institutional support mentoring.

3. Research experience, dissertation writing, professional development institutions have responded on the various local model stages to improve success in $\mathrm{Ph} . \mathrm{D}$ completion rates.

Research information network (RTN) (2011) collected data on the role performance of Ph.D supervisors covering advertising, training, coaching, directing and answering queries. The data revealed some differences between 
supervisors and research students' performance on the nature of the supervisors role performances. As enumerated by teaching and learning center (2011), the roles of the supervisor are director, facilitator, adviser, teacher, supporter, guider, critic, freedom giver and examiner. According to Ndayambaje, (2018), a supervisor should have collegiality, provide practical and professional support to the students.

Abiddin, Hassan and Ahmad (2009) mentioned that the role of the Ph.D supervisors in the British educational system completion system is critical to a successful Ph.D process. Poor supervision can have a significant impact on students, not only limiting the quality of their Ph.D work but also their motivation. Taylor\&Beasley (2005) and NAIRTL(2011) found that both supervisors and students agreed that one role of the Ph.D supervisors was to assist students in general. The amount of assistance that supervisors give to graduate students varies depending upon the stage that the latter have reached. Ph.D supervisors believed that they were contributing by organizing help with skills development in English writing, by collecting relevant literature and through networking or putting students in contact with others working in the area. Reisz (2017) reported that progress creative supervisors need to become involved in stimulating as much creative thinking as possible among students in an attempt to force their development.

As Connel (1985) mentioned that good supervisors are able to adopt a multiplication of roles in relation to the supervisee, Connel (1985) emphasis the role as person centred (teacher/Pupils), task is action centred to teach/to learn and functions is a combination of both roles and tasks.

Ali, Watson \& Dhingra (2006) investigated post graduate research students and research supervisors views on postgraduate students research supervision and the students supervisors relationship in United Kingdom. Data were collected using an online questionnaire with 30 likert type scale statements from 131 post graduate students and 77 supervisors. Following exploratory factor analysis, a three factor model consisting of leadership, knowledge and support was extracted. Both supervisors and students agreed about the attributes of effective supervisors. Both should consider that the supervisors should have interest in their students research. The supervisors must provide timely and constructive feedback and should help on the students where limitations and learning needs are identified. Students believed that Ph.D supervisors must encourage students to work independently and use opportunities to present their work.

Abbidin, Hassan and Ahmad (2009) reviewed the literature on research/graduate students supervision and set out the rights and responsibilities of both students and their supervisors. It provided some useful guidelines for research students and supervisors in a critically important part of graduate education, the supervision of students dissertation writing and research.

Abiddin, Ismail \& Ismail (2011) reviewed effective supervisory approach in handling post graduate research students. It addressed supervision process that is influenced by many factors including the social setting, the personality of the supervisor and student, the relationships developed between them, the expertise of the supervisor and the problems varied among students. Approach of supervision inputs that have influenced supervision and importance of relationship skills in supervision were discussed. The review also discussed the important inputs in supervision process, the social nature of interaction between supervisors and students.

Begin\& Gerard (2013) conducted a research on the role of supervisors in the light of the experience of doctoral students, basing their work on the concept of cognitive apprenticeship. The authors investigated the role that doctoral supervisors should adopt in supporting of their students in light of feedback from supervisors. A total of 553 doctoral students completed on an online survey, in which they were asked to describe their experience using a metaphor. Although the issue of support is rarely referred to directly in the resulting metaphors, the students do seem to suggest that supervisors should adopt a coaching role.

Agu \& Odimegwu (2014) reported doctoral students evaluation of their various supervision models, their satisfaction with these supervision models and development of research related skills. A sample of $310 \mathrm{Ph} . \mathrm{D}$ candidates drawn from a Federal university in eastern part of Nigeria was used for this study. The data generated through a questionnaire was analysed using descriptive statistics and t- test. Results show that face to face interactive models was not only the most frequently used but also the most model adopted in doctoral dissertation supervision than those operating under face-to-face non-interactive models.

Kuluyu (2016) sought to find out quality process in supervision of post graduate students research in public and private universities in Kenya. The researcher sought to establish the influence of quality research supervisory practices on economic growth. Data was gathered through a questionnaire using a sample of 381 randomly selected post graduate students and 66 coordinators of post graduate students. Descriptive statistics were used to summarize data while multiple regressions were used to test hypotheses. The results show that the strongest predictor of the rate 
of growth was supervision training, followed by supervision model, use of mentorship model and use of supervision schedule

Lei \& $\mathrm{Hu}$ (2015) sought to address roles played by doctoral supervisors in their scholarly publishing endeavors. Four important roles played by supervisors were revealed. Prey searchers, managers, manuscript correctors and masters. The result of the study shows that supervisors not only facilitated the doctoral students publishing output but also fostered their apprenticeship in scholarly publishing and the academic community. However, the result also show a general unavailability of sorely-needed detailed and specific guidance on students early publishing attempts and some supervisors limited ability to correct students English manuscripts.

Moskvicheva, Bordovskara \& Darinskaya (2014) conducted a study on the role of students and supervisors interactions on research projects in St-Petersburg State University. A sample consisted of students (bachelors, masters, graduates) and supervisors from different faculties. The questionnaire content analysis, psycho-diagnostics techniques for studying student's intellectual abilities and research potential and 10-point assessment scales for supervisors were used. It was shown that supervisor's evaluations were often inexact and correlated more with external indicators of research activity of students than with their intellectual capacities.

Orellana, Darcher, Perez \& Salenas (2016) conducted a study on improving doctoral success on matching Ph.D students with supervisors. The study identified the supervisory relationship that affect doctoral research conducted at a distance from the students' academic institution. For data collection, semi structured interviews were used. The results indicate important differences between supervisors in the supervision perceptions concerning their own role and students needs regarding supervision and they demonstrate that importance of attending to students needs and on the part of supervisors exercising responsibilities in the development of research competencies of students as is the case of independent criteria and autonomy.

A summary of the literature reviewed above show that none was on supervisor's role performance for Ph.D educational management research completion rates in universities of North Eastern Nigeria, hence, the uniqueness of the study.

\section{Methodology}

The study was conducted using a quantitative descriptive design. The setting of the study was on 13 public and private universities of North Eastern Nigeria. The population of the setting or the study was North Eastern Nigeria. The population of the study was 180 comprising of $100 \mathrm{Ph} . \mathrm{D}$ students and $80 \mathrm{Ph} . \mathrm{D}$ supervisors in the educational management departments from 13 public and private universities in North Eastern Nigeria. All the 180 supervisors and students were utilized for the study. A 25 questionnaire items was developed with five likert like response scale of Very high level, high level, moderate level, low level and very low level. The questionnaire was developed from five variables of Ph.D supervision stages in the purpose of the study: Section A-formulation of the study, Section B-establishing the methods, Section C-discussing the results of the study, Section D-presentation of seminars and conferences, Section E-publication of journal articles and Section F-writing the dissertation.

After development of the questionnaire, it was reviewed by three experienced Ph.D supervisors from educational management unit of physical Sciences Education department of Modibbo Adama University of Technology Yola, Nigeria. Content validity was established and face validity and appropriateness of the content was determined. The author used feedback about the questionnaire relating to its length and comprehensibility.

The questionnaire was pilot tested with $10 \mathrm{Ph} . \mathrm{D}$ students and 5 supervisors from educational management departments of universities in North Central Nigeria. The reliability coefficient was determine through Cronback alpha with reliability coefficient of 0.86 . Data was collected through six (6) research assistants with each handling universities in the six states of North Eastern Nigeria. Each of them administered the questionnaire and collected same on the sport with hundred (100) percent rate of return.

The data collected was analyzed descriptively through mean and standard deviation. The decision rule for answering the research questions was that if the mean is above 3.5, it shows high level, 3.5 indicate moderate level and below 3.5 as low level.

\section{Result}

Study result was presented in the order in which the purpose were stated.

4.1 Research Question One: what is the level of Ph.D supervisor's role performance of formulation of the study on $\mathrm{Ph} . \mathrm{D}$ education management research completion rates in universities of North Eastern Nigeria. 
Table 1. Mean and standard deviation of responses from educational management research Ph.D supervisors and students on supervisor's role performance in formulation of the study for completion rates in universities of North Eastern Nigeria

\begin{tabular}{|c|c|c|c|c|}
\hline \multirow[t]{2}{*}{$\mathrm{S} / \mathrm{N}$} & \multirow[t]{2}{*}{ Assessment Role performance } & $\mathrm{N}^{\mathrm{X1}}=80$ & $\mathrm{~N}^{\mathrm{X} 2}=100$ & \multirow[t]{2}{*}{ REMARK } \\
\hline & & $\mathrm{X} 1$ & $\mathrm{X} 2 \partial$ & \\
\hline 1 & Selection of suitable research topics & $434(0.5)$ & $4.39(0.97) 4.4$ & High \\
\hline 2 & Planning of manageable research topic & $4.77(0.48)$ & $4.48(0.86) 4.6$ & High \\
\hline 3 & Sufficient familiarity with field of study & $4.57(0.72)$ & $4.40(64) 4.5$ & High \\
\hline 4 & Provide guidance & $4.51(0.56)$ & $4.62(0.86) 4.7$ & High \\
\hline \multirow[t]{2}{*}{5} & Willingfulness to gain familiarity & $4.74(0.50)$ & $4.39(0.76) 4.6$ & High \\
\hline & Overall mean & & 4.6 & High \\
\hline
\end{tabular}

Source: Field Work

$\mathrm{X}_{1}=\mathrm{Ph} . \mathrm{D}$ supervisors

$\mathrm{X}_{2}=$ Ph.D students

Table 1 shows Ph.D supervisors high (4.6) role performance in formulation of the research study in educational management research completion rates in universities of North Eastern Nigeria. This means that Ph.D supervisor's role performance in formulation of research study for educational management research completion rates was high in universities of North Eastern Nigeria.

4.2 Research Question Two: what is the level of Ph.D supervisor's role performance on educational management research completion rates in universities of North Eastern Nigeria.

Table 2. Mean and standard deviation of Ph.D supervisors and students on supervisor's role performance in establishing research method in educational management research completion rates in universities of North Eastern Nigeria

\begin{tabular}{|c|c|c|c|c|}
\hline \multirow[t]{2}{*}{$\mathrm{S} / \mathrm{N}$} & \multirow[t]{2}{*}{ Assessment Role performance } & $\mathrm{N}^{\mathrm{X} 1}=80$ & $\mathrm{~N}^{\mathrm{X} 2}=100$ & \multirow[t]{2}{*}{ REMARK } \\
\hline & & $\mathrm{X} 1$ & $\mathrm{X} 2 \quad \partial \mu$ & \\
\hline 1 & Research environment is safe & $4.39(0.67)$ & $4.39(0.75) 4.4$ & High \\
\hline 2 & The research environment is healthy & $4.39(0.95)$ & $4.32(0,67) 4.4$ & High \\
\hline 3 & $\begin{array}{l}\text { Research environment is free from harassment, } \\
\text { discrimination and conflict }\end{array}$ & $4.33(0.58)$ & $4.57(0.69) 4.5$ & High \\
\hline 4 & $\begin{array}{l}\text { Compliance with the university requirements of } \\
\text { submitting reports }\end{array}$ & $3.52(0.94)$ & $3.80(1.07) 3.7$ & High \\
\hline \multirow[t]{2}{*}{5} & Monitoring students' performance & $3.94(0.89)$ & $3.58(0.98) 3.8$ & High \\
\hline & Overall mean & & 4.2 & High \\
\hline
\end{tabular}

Source: Field Work

$\mathrm{X}_{1}=\mathrm{Ph} . \mathrm{D}$ Supervisors

$\mathrm{X}_{2}=\mathrm{Ph} . \mathrm{D}$ Students

Table 2 indicated supervisors high (4.2) role performance on establishing research method on Ph.D educational management research completion rates in universities of North Eastern Nigeria. It also means that Ph.D supervisor's role performance in establishing research methods for educational management research completion rates was high in universities of North Eastern Nigeria. 
4.3 Research Question Three: What is the level of Ph.D supervisor's role performance in discussing the research results for educational management research completion rates in universities of North Eastern Nigeria.

Table 3. Mean and standard deviation of supervisors and students on Ph.D supervisor's role performance in discussing results for educational management research completion rates in universities of North Eastern Nigeria

\begin{tabular}{|c|c|c|c|c|}
\hline \multirow[t]{2}{*}{$\mathrm{S} / \mathrm{N}$} & \multirow[t]{2}{*}{ Assessment Role Performance } & $\mathrm{N}^{\mathrm{X} 1}=80$ & $\mathrm{~N}^{\mathrm{X} 2}=100$ & \multirow[t]{2}{*}{ REMARK } \\
\hline & & $\overline{\mathrm{X} 1} \partial$ & $\overline{\mathrm{X} 2} \partial \mu$ & \\
\hline 1 & Supervisor is a accessible to students & $3.90(0.93)$ & $3.89(0.90) 3.9$ & High \\
\hline 2 & $\begin{array}{l}\text { The supervisors hold consultation on } \\
\text { student academic performance and research }\end{array}$ & $3.99(0.85)$ & $3.84(1.03) 4.0$ & High \\
\hline 3 & $\begin{array}{l}\text { Discuss students' academic progress and } \\
\text { research }\end{array}$ & $3.94(0.093)$ & $3.80(01.07) 3.9$ & High \\
\hline 4 & Meet the students one-on-one & $3.90(0.93)$ & $4.03(0.80) 4.0$ & High \\
\hline \multirow[t]{2}{*}{5} & $\begin{array}{l}\text { The supervisor does not embarrass student } \\
\text { in the presence of peers }\end{array}$ & 3.94(0.88) & $3.89(0.90) 3.9$ & High \\
\hline & Overall mean & & 3.9 & High \\
\hline
\end{tabular}

Source: Field Work

$\mathrm{X}_{1}=\mathrm{Ph} . \mathrm{D}$ Supervisors

$\mathrm{X}_{2}=\mathrm{Ph} . \mathrm{D}$ Students

Table 3 above shows Ph.D supervisor high (3.9) role performance in discussing research results for educational management research completion rates in universities of North Eastern Nigerian. This supervisor's role performance in discussing results for Ph.D educational management research completion rates is high in universities of North Eastern Nigeria.

4.4 Research Question Four: what is the level of Ph.D supervisor's role performance in presentation of seminars and conferences for educational management research completion rates in universities of North Eastern Nigeria.

Table 4. Mean and standard deviation of Ph.D supervisors and students on supervisor's role performance of presentation of seminars/conferences for educational management research completion rates in universities of North Eastern Nigeria

\begin{tabular}{|c|c|c|c|c|}
\hline \multirow[t]{2}{*}{$\mathrm{S} / \mathrm{N}$} & \multirow[t]{2}{*}{ Assessment Role Performance } & $\mathrm{N}^{\mathrm{X} 1}=80$ & $\mathrm{~N}^{\mathrm{X} 2}=100$ & \multirow[t]{2}{*}{ REMARK } \\
\hline & & $\mathrm{X} 1 \quad \partial$ & $\mathrm{X} 2 \quad \partial \quad \mu$ & \\
\hline 1 & $\begin{array}{l}\text { Supervisors encourage students to make } \\
\text { presentation of research findings within the } \\
\text { university. }\end{array}$ & $3.94(0.89)$ & $3.89(0.97) 3.9$ & High \\
\hline 2 & $\begin{array}{l}\text { Supervisors encourage students to make } \\
\text { presentation outside at scholarly level. }\end{array}$ & $4.27(0.83)$ & $3.85(1.29) 4.1$ & High \\
\hline 3 & $\begin{array}{l}\text { Supervisors encourage students to make } \\
\text { presentation at professional forums }\end{array}$ & $4.14(0.76)$ & $3.98(0.88) 4.1$ & High \\
\hline 4 & $\begin{array}{l}\text { Supervisors guide the students to prepare a } \\
\text { quality presentation }\end{array}$ & $4.38(1.07)$ & $4.00(0.83) 4.2$ & High \\
\hline \multirow[t]{2}{*}{5} & $\begin{array}{l}\text { Supervisors encourage students to deliver } \\
\text { quality presentation. }\end{array}$ & $4.21(0.83)$ & $3.98(0.84) 4.1$ & High \\
\hline & Overall mean & & 4.1 & High \\
\hline
\end{tabular}

Source: Field Work

$\mathrm{X}_{1}=\mathrm{Ph} . \mathrm{D}$ Supervisors

$\mathrm{X}_{2}=$ Ph.D Students 
Table 4 above shows high (4.1) Ph.D supervisors role performance in presentation of seminars/conferences for educational management research completion rates in universities of North Eastern Nigeria.It means that supervisors role performance in presentation of seminars/conference for educational management research completion rates was high in universities of North Eastern Nigeria.

4.5 Research Question Five: What is the level of Ph.D supervisor's role performance in publication of journal articles for educational management research completion rates in universities of North Eastern Nigeria.

Table 5. Mean and standard deviation of responses from Ph.D supervisors and students on supervisor's role performance in publication of journal articles for educational management research completion rates in universities of North Eastern Nigeria

\begin{tabular}{|c|c|c|c|c|}
\hline \multirow[t]{2}{*}{$\mathrm{S} / \mathrm{N}$} & \multirow[t]{2}{*}{ Assessment Role Performance } & \multirow{2}{*}{$\begin{array}{l}\mathrm{N}^{\mathrm{X} 1}=80 \\
\mathrm{X} 1\end{array}$} & $\mathrm{~N}^{\mathrm{X} 2}=100$ & \multirow[t]{2}{*}{ REMARK } \\
\hline & & & $\overline{\mathrm{X} 2} \quad \partial \mu$ & \\
\hline 1 & $\begin{array}{l}\text { Supervisors identify the important themes } \\
\text { of the study to be formulated in the articles . }\end{array}$ & $4.19(0.9)$ & $4.19(0.79) 4.2$ & High \\
\hline 2 & $\begin{array}{l}\text { Supervisors acknowledge the contributions } \\
\text { of the students via joint authorship }\end{array}$ & $3.83(1.21)$ & $4.00(0.83) 3.9$ & High \\
\hline 3 & $\begin{array}{l}\text { Supervisors identifies the relevant journal } \\
\text { for the article }\end{array}$ & $4.21(0.84)$ & $4.45(0.69) 4.3$ & High \\
\hline 4 & $\begin{array}{l}\text { Supervisors guide the students in formatting } \\
\text { the articles based on guidelines }\end{array}$ & $3.94(0.92)$ & $4.43(0.73) 4.2$ & High \\
\hline \multirow[t]{2}{*}{5} & $\begin{array}{l}\text { Supervisors are consulted for students draft } \\
\text { of the paper }\end{array}$ & $4.45(0.69)$ & $3.99(0.91) 4.2$ & High \\
\hline & Overall mean & & 4.2 & High \\
\hline
\end{tabular}

Source: Field Work

$\mathrm{X}_{1}=\mathrm{Ph} . \mathrm{D}$ Supervisors

$\mathrm{X}_{2}=$ Ph.D Students

The Ph.D supervisors role performance was high (4.2) in publication of journal articles for educational management research completion rates in universities of North Eastern Nigeria. This means that Ph.D supervisor's role performance was high in publication of journal articles for educational management research completion rates in universities of North Eastern Nigeria.

4.6 Research Question Six: What is the level of Ph.D supervisor's role performance in writing of dissertation for educational management research completion rates in universities of North Eastern Nigeria. 
Table 6. Mean and standard deviation of responses from Ph.D supervisors and students on supervisor's role performance in writing of the dissertation for educational management research completion rates in universities of North Eastern Nigeria

\begin{tabular}{|c|c|c|c|c|}
\hline \multirow[t]{2}{*}{$\mathrm{S} / \mathrm{N}$} & \multirow[t]{2}{*}{ Assessment Role Performance } & \multirow{2}{*}{$\frac{\mathrm{N}^{\mathrm{X} 1}=80}{\mathrm{X} 1} \partial$} & $\mathrm{N}^{\mathrm{X} 2}=100$ & \multirow[t]{2}{*}{ REMARK } \\
\hline & & & $\overline{\mathrm{X} 2} \partial \mu$ & \\
\hline 1 & $\begin{array}{l}\text { Supervisors assess the quality of } \\
\text { dissertation }\end{array}$ & $4.23(0.56)$ & $4.18(0.72) 4.2$ & High \\
\hline 2 & $\begin{array}{l}\text { Supervisors approve for submission of } \\
\text { dissertation }\end{array}$ & $4.27(0.66)$ & $4.20(0.72) 4.2$ & High \\
\hline 3 & $\begin{array}{l}\text { Supervisor identifies the internal and } \\
\text { external examiners }\end{array}$ & $3.83(1.21)$ & $4.14(0.85) 4.1$ & High \\
\hline 4 & The supervisors examines dissertation & $4.35(0.62)$ & $4.20(0.72) 4.3$ & High \\
\hline \multirow[t]{2}{*}{5} & $\begin{array}{l}\text { Supervisors submits a report to board of } \\
\text { post graduates studies }\end{array}$ & $4.27(0.62)$ & $4.28(0.69) 4.2$ & High \\
\hline & Overall mean & & 4.2 & High \\
\hline
\end{tabular}

Source: Field Work

$\mathrm{X}_{1}=\mathrm{Ph} . \mathrm{D}$ Supervisors

$\mathrm{X}_{2}=\mathrm{Ph} . \mathrm{D}$ Students

The supervisors role performance was high (4.2) in writing of dissertation for Ph.D educational management completion rates in universities of North Eastern Nigeria. This means that supervisor's role performance was high in writing of dissertation for Ph.D educational management completion rates in universities of North Eastern Nigeria.

4.7 Research Question Seven: What is the level of Ph.D supervisor's general role performance on educational management research completion rates in universities of North Eastern Nigeria.

Table 7. Mean and standard deviation of responses from Ph.D supervisors and students on supervisor's general role performance for educational management research completion rates in universities of North Eastern Nigeria

\begin{tabular}{|c|c|c|c|c|}
\hline \multirow[t]{2}{*}{$\mathrm{S} / \mathrm{N}$} & \multirow[t]{2}{*}{ Assessment Role Performance } & $\mathrm{N}^{\mathrm{X} 1}=80$ & $\mathrm{~N}^{\mathrm{X} 2}=100$ & \multirow[t]{2}{*}{ REMARK } \\
\hline & & $\mathrm{X} 1 \quad \partial$ & $\mathrm{X} 2 \partial \mu$ & \\
\hline 1 & Formulating research study & $4.29(0.72)$ & $4.24(0.89) 4.3$ & High \\
\hline 2 & Establishing the research methods & $4.39(0.65)$ & $4.28(0.69) 4.3$ & High \\
\hline 3 & Discussing research results & $4.19(0.79)$ & $4.40(0.69) 4.1$ & High \\
\hline 4 & Presentation of seminars and conferences & $3.94(0.93)$ & $4.39(0.98) 4.5$ & High \\
\hline 5 & Publication of journals articles & $4.57(0.72)$ & $4.40(0.69) 4.5$ & High \\
\hline 6 & Writing the dissertation & $3.58(0.98)$ & $3.80(1.07) 3.7$ & High \\
\hline & Overall mean & & 4.2 & High \\
\hline
\end{tabular}

Source: Field Work

$\mathrm{X}_{1}=\mathrm{Ph} . \mathrm{D}$ Supervisors

$\mathrm{X}_{2}=$ Ph.D Students 
Table 7 shows high (4.2) Ph.D supervisors general roles performance for educational management research completion rates in universities of North Eastern Nigeria. It means that Ph.D supervisor's general roles performance was high for educational management research completion rates in universities of North Eastern Nigeria.

\subsection{Findings of the Study}

Tables 1-7 presented descriptive statistics of mean and standard deviation for each statement from respondents' views about Ph.D supervisor's role performance for educational management research completion rates. Means and standard deviations were presented for supervisors and students on each $\mathrm{Ph}$. D supervisor's role performance and the general role performance for educational management research completion rates. Respondents show high Ph.D supervisors role performance in formulation of the research study (4.6) establishing research methods (4.2) discussing the research results (3.9) presentation of seminars/conferences (4.1), publication of journal articles (4.2), writing of dissertation (4.2) and general role performance (4.2) for educational management research completion rates in universities of North Eastern Nigeria.

\subsection{Discussion of Findings}

The findings of this study were discussed in relation to the five six stages and general supervisor's role performance for Ph.D educational management research completion rates. The first stage was formulation of the study. Ph.D supervisor's role performance in formulation of research study was high in educational management completion rates. The overall mean shows high supervisors role performance on formulation of research study. The finding from Table 1 is not consistent with RTN (2011) which shows significant difference between Ph.D supervisors and students on supervisor's role performance on formulation of the research study. Information gathering from universities in North Eastern Nigeria through discussions however tends to support the finding of the study.

The finding from Table 2 shows high supervisors' role performance on establishing the research method for Ph.D educational management research completion rates. The overall mean shows high $\mathrm{Ph} . \mathrm{D}$ supervisor's role performance. This finding is supported by Uribe (2017) which reported that supervisors believed in organizing help with skills, developing, englishing and writing by working and collecting relevant literature and through network and putting students in contact with others working in the area. Therefore, the finding that supervisor's role performance on establishing research method for Ph.D educational management research completion rates is not misleading.

The finding in Table 3 shows that Ph.D role performance in discussing the results of the study is high for educational management research successful completion rates. These findings differ from the assertion of Begin\& Gerard (2013) which pointed out that the issue of support is rarely referred to directly in the resulting metaphors but supervisors should adopt a coaching role.

The findings of this research with regard to Ph.D supervisors role performance in presentation of seminars and conferences indicate that the role performance is high (Table 4). The overall mean of the items show high role performance. This infers that supervisors support Ph.D educational management research models in presentation of seminars/conference. This also indicates that students are prepared for presentation of seminars/conferences by those supervisors.

Findings of the study in Table 5 show supervisors' role performance in publication of journal articles for Ph.D educational management research successful completion rates. The overall mean role performance of the items indicates high role performance. This finding is consistent with the assertion of Lei\& Hu (2015) which show that supervisors not only facilitated the doctoral students publishing outputs but also fostered their apprenticeship in scholarly publishing and the academic community.

Table 6 shows high supervisor's role performance in writing the dissertation for Ph.D educational management research completion rates. This means that supervisor's role performance on writing the dissertation in Ph.D educational management research completion rates is high.

The finding in Table 7 also revealed high general role performance in all stages of supervision for Ph.D educational management research completion rates. This also means that supervisors perform their general role of supervision for $\mathrm{Ph} . \mathrm{D}$ educational management research completion rates in North Eastern Nigeria.

\section{Conclusion}

This study assessed Ph.D supervisor's role performance for educational management research completion rates. It considered supervisors role performance in formulation of the research study, establishing research method, discussing the research results of the study, presentation of seminars/conferences, publication of journal articles and writing of the dissertation. The result shows that Ph.D supervisor's role performance in all stages for educational 
management research completion rates is high. Therefore, conclusion of the study was that Ph.D supervision items perform general roles in all the stages for educational management research completion rates of universities in North Eastern Nigeria.

\subsection{Recommendation}

Further research is recommended to assess student's role performance for timely $\mathrm{Ph}$.D educational management research completion rates in North Earthen Nigeria. It will be used to examine factors determining Ph.D educational management research timely and successful completion rates in universities of North Eastern Nigeria. This study is significant interms of improving Ph.D educational management supervision and completion rates.

\section{References}

Abiddin, N. Z., Hassan, A., \& Ahmed, A. (2009). Research students supervision: An approach to good supervisory practice. Open Educational Journal, 2, 11-16. https://doi.org/10.2174/1874920800902010011

Abiddin, N. Z., Ismail, A., \& Ismail, A. (2011). Effective supervisory approach in enhancing postgraduate research students. International journal of Humanities and Social Science, 1(1), 206-2017.

Agu, N., \& Odimegwu, C. O. (2014). Doctoral dissertation: identification and evaluation of models. Educational Research Journal, 1-9. https://doi.org/10.1155/2014/790750

Ali, P. A., Watson, R., \& Dhingra, K. (2016). Postgraduate research students and their supervisors attitude towards supervision. International Journal of Doctoral Studies, 11, 217-241. https://doi.org/10.28945/3541

Aryanitakis, J. (2017). Factors contributing to high Ph.D completion rates. Word Press.

Begin, C., \& Gerard, L. (2013). The role of supervision in light of experience of doctoral students. Policy Futures in Education, 11(3), 207-276. https://doi.org/10.2304/pfie.2013.11.3.267

Bogle, D. (2017). The Autralian approach to improving Ph.D completion rates. London: Leaque of European Research Universities.

Carton, J. (2014). Research supervisors support and development: Review of Policy, Practices and Procedures in five U21 Partner Universties. Universities 21 and UCD International.

Cartons, J., QFarrel, C., \& Kelly, A. (2013). Developing an institutional framework for supporting supervisors of research students: lessons learned from a unique inter-institutional project in Ireland. Journal of the European Higher Education Area, (2).

Cattell, R. B. (1996). The screen test for the test of factors. Multivariate Behavioural Research, 1, 245-276. https://doi.org/10.1207/s15327906mbr0102_10

Chiappetta-Swanson, C., \& Watt, S. (2011). Good practice in the supervision and mentoring of post-graduate students. Centre for Leadership in Learning, MacMaster University Otario.

Connel, R. (1985). How to supervise a Ph.D. Vestes, 2.

Howard ,G., \& Powell, S. (2005). Doctoral study in contemporary higher education. U.K: McGraw-Hill education.

Kuluyu, V. (2016). Status of quality supervision of post graduates research and its influence on the rate of economic growth: A case study of universities in Kenya. International Journal of Businesses Management and Administration, 5(1), 001-007.

Lee, A. (2013). Are doctoral programme doing what we think they are?. Journal of Public Policy and Management, 33(2). https://doi.org/10.1080/09540962.2013.763423

Lee, H., Carina, D., \& Campbell, P. (2007). Naturesguidefor mentors. Nature, 447, 791-797. https://doi.org/10.1038/447791a

Lei, J., \& Hu, G. (2015). Apprenticeship in scholarly publishing: A students' perspective on doctoral supervisory roles. Publications, 3, 27-42. https://doi.org/10.3390/publications3010027

Louw, T., \&Muller, J. (2014). Literature review on models of Ph.D. Capetown: chet.

Manathunga, C. (2005). Early warning signs in post-graduate research education.A different approach to timely completion. Teaching in Higher Education, 10(20), 2019-233. https://doi.org/10.1080/1356251042000337963

Manathunga, C. (2007). Supervision as mentoring: The role of power and boundary crossing. Studies in Continuing Education, 29(2), 207-221. https://doi.org/10.1080/01580370701424650 
Moskvicheva, N., Bordovskala, N., \& Doriusau Kaya, L. (2014). Role of students and supervisors. Interactions in research projects: expectations and evaluations. Science Direct, 576-583. https://doi.org/10.1016/j.sbspro.2015.01.163

NAIRTL (National Academy for integration of Research, Teaching and Learning). (2011). Developing an institutional framework for supporting supervisors of research students: a practical guide. Retrieved from http://books.coogle.ie/books

Nayar, S., \& Mccallun, A. (2012). Post-graduate research supervision: a critical review of current practice. Teaching in Higher Education, 17(1), 63-74. https://doi.org/10.1080/13562517.2011.590979

Ndakala, A. J. O. (2008). Rolesandresponsibilitiesin Ph.D. Retrieved from htt://www.unonbi.ac.ke

Ndayambaje, I. (2018). Effect of supervision on timely completion of Ph.D programmes. Rwandan Journal of Education, 4(2), 57-70.

Nulty, D., Kiley, M., \& Meyers, N. (2008). Promoting and recognizing excellence in the supervision of research students: an evidence-based framework. Assessment and Evaluation in Higher Education, 1-14.

Orellana, M. L.,Darder, A., Perez, A., \& Salinas, J. (2016). Improvingdoctoral successful matching of Ph.D students with supervisors. International Journal of Doctoral Studies, 11, 87-103. https://doi.org/10.28945/3404

Pearson, M., \& Brew, A. (2002). Research training and supervision development. Studies in Higher Education, 27(2), 135-150. https://doi.org/10.1080/03075070220119986c

Reisz, M. (2017). Assessing Ph.D supervisors leads to higher completion rates. Times Higher Education.

Research Information Network. (2011). The role of research supervisors in information literacy. London: Research Information Network.

Russell, R. (2017). Development in doctoral education and training. Third International Conference in University of Adelaide, Australia.

Sinclair, M. (2004). The pedagogy of good Ph.D supervision: A national cross-disciplanary investigation of Ph.D supervision. Canberra: Commonwealth of Australia.

Taylor, S., \& Beasley, N. (2005). Handbook for doctoral supervisors. London: Routledge Falmer. https://doi.org/10.4324/9780203415740

Teaching and Learning Centre. (2015). Ph.D supervisors. LSE Ph.D Academy.

Uribe, D. (2017). Tracking the performance of those who supervise doctoral students. Australia: European University Associations Council for doctoral Education Conference

Wright, T., \& Cochrane, R. (2010). Factors influencing successful submission of Ph.D dissertation. Studies in Higher Education, 25(2), 181-195. https://doi.org/10.1080/713696139 